\title{
Article \\ Achieving Partial Nitritation in Anammox Start-Up Environment
}

\author{
Sabin Pathak ${ }^{1, *}$, Shuai Wang ${ }^{2, *}$ and Eshetu Janka ${ }^{1}$ \\ 1 Department of Process, Energy and Environmental Technology, University of South-Eastern Norway, \\ 3918 Porsgrunn, Norway; Eshetu.j.wakjera@usn.no \\ 2 Biowater Technology AS, 3115 Tønsberg, Norway \\ * Correspondence: spathak702@gmail.com (S.P.); sw@biowatertechnology.com (S.W.)
}

Citation: Pathak, S.; Wang, S.; Janka, E. Achieving Partial Nitritation in Anammox Start-Up Environment. Water 2022, 14, 229. https: / / doi.org/ $10.3390 /$ w14020229

Academic Editor:

Alexandre T. Paulino

Received: 26 November 2021

Accepted: 10 January 2022

Published: 13 January 2022

Publisher's Note: MDPI stays neutral with regard to jurisdictional claims in published maps and institutional affiliations.

Copyright: (C) 2022 by the authors. Licensee MDPI, Basel, Switzerland. This article is an open access article distributed under the terms and conditions of the Creative Commons Attribution (CC BY) license (https:// creativecommons.org/licenses/by/ $4.0 /)$.

\begin{abstract}
Removing ammonium via the partial nitritation anammox (PNA) process has been widely applied because of its cost and energy effectiveness. However, the first stage of PNA, partial nitritation, is hard to implement practically due to the challenging suppression of nitrate oxidizing bacteria (NOB) and should be achieved in the anammox environment to extend it to one stage PNA. Hence, this article evaluates different techniques, such as the combination of low dissolve oxygen (DO) and high free ammonia (FA), and the intermittent aeration cycle to achieve partial nitritation in an anammox start-up environment. For this purpose, a $10.5 \mathrm{~L}$ lab-scale moving bed biofilm reactor was set up and fed with synthetic wastewater and the transformation of influent ammonium into nitrate and nitrite was measured. The results showed that, despite applying low DO and higher free ammonia than the inhibition range of NOB, the nitrate production rate (NPR) was consistently higher than the nitrite accumulation rate (NAR), signifying no sufficient NOB suppression, partial nitritation under continuous aeration and up to a $0.27 \mathrm{gN} / \mathrm{m}^{2} \cdot \mathrm{d}$ surface ammonium loading rate (SALR). Higher SALR than $0.27 \mathrm{gN} / \mathrm{m}^{2} \cdot \mathrm{d}$ could result in partial nitritation since nitrogen compounds transformation was closer to partial nitritation when the reactor was subjected to $0.27 \mathrm{gN} / \mathrm{m}^{2} \cdot \mathrm{d}$ rather than $0.14 \mathrm{gN} / \mathrm{m}^{2} \cdot \mathrm{d}$. Lifting up the SALR, on the other hand, results in a bad anammox environment and cannot prolong it to one-stage PNA. An intermittent aeration cycle with four different cycle lengths sets, obtained by monitoring nitrogen compound transformation, was, therefore, applied to the reactor. The relatively shorter aerobic length of $10 \mathrm{~min}$ ON and 30 OFF intermittent aeration cycle with $0.5 \mathrm{mg} / \mathrm{L}$ aerated DO was successful in achieving the partial nitritation with NPR, NAR, and ammonium removal efficiency (ARE) values of $17 \%, 78 \%$, and $37 \%$, respectively, showing that shorter aerated length suppresses NOB to a high degree due to less available time for NOB after oxygen starvation.
\end{abstract}

Keywords: partial nitritation; dissolve oxygen; intermittent aeration cycle; anammox

\section{Introduction}

Partial nitritation is the process by which ammonia oxidizing bacteria (AOB) convert half of the ammonium concentration in wastewater to nitrite in an aerobic environment (Equation (1)) [1]. Based on the energy source, the AOB bacteria are chemolithoautotroph, which means that they obtain the energy from the oxidation of inorganic compounds and utilize carbon dioxide as carbon source for cell synthesis. In recent years, partial nitritation has been considered a crucial mechanism, as it provides sufficient substrates for the anammox process.

$$
1.0 \mathrm{NH}_{4}^{+}+0.75 \mathrm{O}_{2}+\mathrm{HCO}_{3}^{-} \rightarrow 0.5 \mathrm{NH}_{4}^{+}+0.5 \mathrm{NO}_{2}^{-}+\mathrm{CO}_{2}+1.5 \mathrm{H}_{2} \mathrm{O}
$$

Anammox process is the simultaneous consumption of nitrite and ammonium to yield nitrogen gas by anammox bacteria in an anoxic environment (Equation (2)) [2]. Since 
wastewater has low nitrite content, partial nitritation is often combined with an anammox process for the complete nitrogen removal from the wastewater, known as the partial nitritation anammox process (PNA). This combination can be carried out in a single reactor

$$
\begin{gathered}
1.0 \mathrm{NH}_{4}^{+}+1.32 \mathrm{NO}_{2}^{-}+0.066 \mathrm{HCO}_{3}^{-}+0.13 \mathrm{H}^{+} \rightarrow 1.02 \mathrm{~N}_{2}+0.26 \mathrm{NO}_{3}^{-}+ \\
0.066 \mathrm{CH}_{2} \mathrm{O}_{0.5} \mathrm{~N}_{0.15}+2.03 \mathrm{H}_{2} \mathrm{O}
\end{gathered}
$$

(one-stage PNA) as well as in two reactors (two-stage PNA). In the attached growth biological wastewater treatment process, the biofilm with the combination of AOB in the outer layer and anammox in the inner layer in one reactor is responsible for one-stage PNA (Figure 1), whereas distinct biofilm for each phase in a separate reactor result in two-stage PNA. The PNA is a more cost-effective nitrogen removal approach than the conventional nitrification-denitrification process because it does not require organic carbon, requires $63 \%$ less aeration (i.e., energy) [3], and reduces the sludge yields by approximately $80 \%$ [4]. In addition, carbon dioxide produced in the preceding partial nitritation step (Equation (1)) is utilized by anammox bacteria, resulting in a lower carbon footprint than the traditional nitrogen removal technique [5]. However, the practical implementation of the partial nitritation process is quite challenging due to the growth of nitrite oxidizing bacteria (NOB). If a significant number of NOB population is present, the nitrite produced by partial nitritation could be completely oxidized to nitrate. Therefore, the NOB bacteria should be suppressed to prevent nitrite accumulation and ensure efficient nitrogen removal through the PNA process.

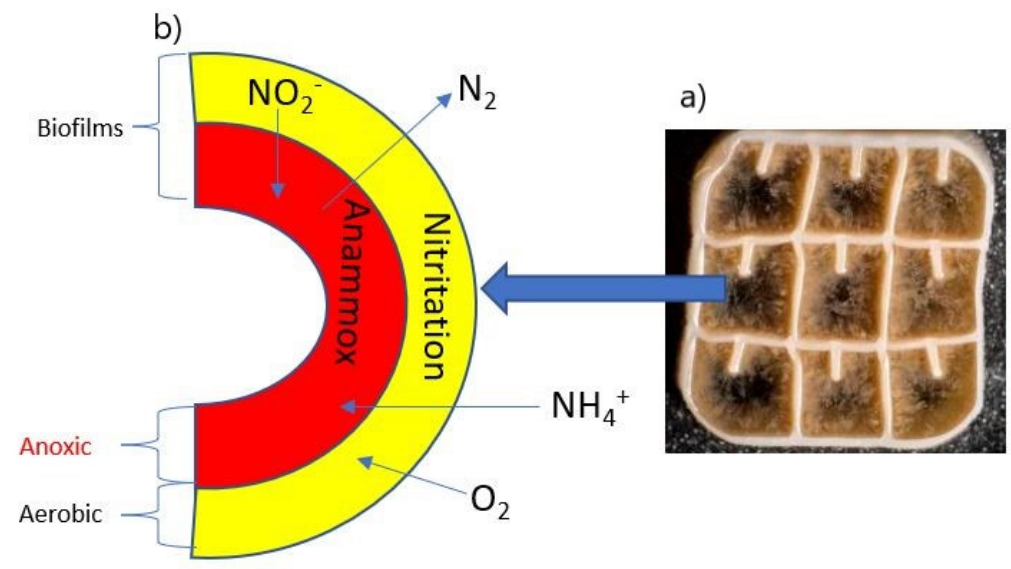

Figure 1. Simultaneous partial nitritation and anammox process in the biofilm: (a) figure of biocarrier along with biofilm; (b) different biochemical process in different layer of biofilm [3].

Several operational strategies, such as high free ammonia (FA) concentration [6], low dissolved oxygen (DO) [7], intermittent aeration [8], chemical dosing [9], and elevated ammonium loading rate [10] have been used to achieve quick and stable partial nitritation.

The free ammonia (FA) concentration higher than $8-120 \mathrm{mg} / \mathrm{L}$ inhibits the AOB bacteria, while $0.08-0.82 \mathrm{mg} / \mathrm{L}$ FA concentration hinders the NOB activity [11]. Hence, the application of relatively higher free ammonia (i.e., in between inhibition range of AOB and $\mathrm{NOB}$ ) could enhances nitrite accumulation. To maintain the right temperature, $\mathrm{pH}$, and inflow ammonium concentration can help to keep the right amount of FA in the system [11].

Because the NOB has a higher DO half-saturation constant $\left(\mathrm{K}_{\mathrm{s}}\right)$ value than the AOB (0.032-0.48 for AOB vs. 0.7-5.3 for NOB), NOB has a slower growth rate than the AOB under low DO concentrations [3]. However, a recent study found that partial nitritation is impossible even at low DO concentrations because of the growth of Nitrospira species of NOB bacteria, which has a comparably lower DO half-saturation constant $\left(\mathrm{K}_{\mathrm{s}}\right)$ value than AOB bacteria (i.e., 0.33) [12]. 
Consequently, an intermittent aeration cycle is an effective approach to suppress NOB bacteria and is considered as a robust technique because it can be applied in almost all types of reactors. In this strategy, the aerobic and anaerobic condition is applied in the reactor alternatively in short cycle (Figure 2). By the alternation of such environments, it is possible to suppresses NOB bacteria because of its lower starvation recovery dynamics compared to AOB [13]. When the reactor shifts from the anoxic phase to the aerobic phase, AOB, which has a higher recovery time, acts upon the wastewater immediately, but NOB takes a longer time to convert nitrite to nitrate because of lower starvation recovery dynamics. As a result, nitrite is accumulated in the reactor, and before NOB starts to convert nitrite to nitrate, aeration should turn off to shift the reactor environment from aerobic phase to anoxic phase. Hence, the main principle behind the intermittent aeration cycle is to suppress NOB using starvation recovery time of NOB, and the actual aerobic length should be similar or less than that time for complete NOB suppression. In addition, under this strategy, AOB produces two compounds, which are inhibitory of NOB growth: (i) hydroxylamine $\left(\mathrm{NH}_{2} \mathrm{OH}\right)$, formed when aeration is suddenly turned off [14], and (ii) nitric oxide (NO), which is produced by performing denitrification under anoxic conditions [15]. However, maintaining optimum cycle lengths (i.e., aerobic length and anoxic length) is quite challenging due to a lack of knowledge of the actual recovery time of NOB.

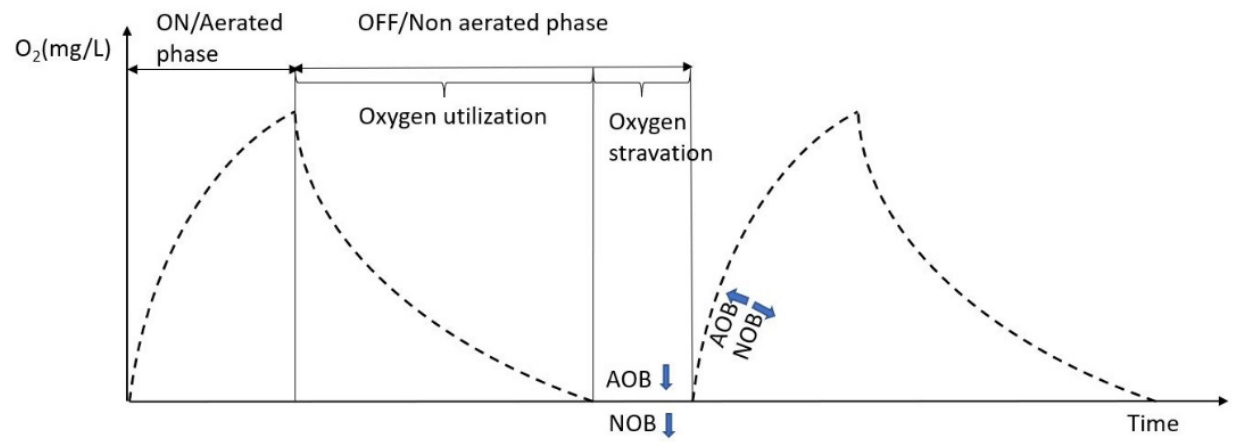

Figure 2. DO profile in the intermittent aeration cycle adopted and modified from Bakke, R [16].

Moreover, volatile fatty acids (VFA) like formic, acetic, propionic, and n-butyric, which have a high inhibitory effect on the NOB but no inhibitory effect on the AOB, can be used to achieve partial nitritation [17]. A study carried out by Peng et al. [18] on several inhibition compounds for nitrification shows that chlorate, cyanide, azide (i.e., conjugate base of hydrazoic acid), and hydrazine have a greater inhibition effect on the NOB than AOB. Therefore, the addition of such compounds in an appropriate amount suppresses NOB without affecting $\mathrm{AOB}$, resulting in partial nitritation.

The main aim of this experimental test was to obtain rapid partial nitritation, which can then be expanded into a one-stage PNA. For this, partial nitritation should be accomplished in an anammox-friendly environment; otherwise, altering operating conditions for anammox start-up may affect achieved partial nitritation and, subsequently, the anammox process. The study has proposed the potential of two distinct strategies for stable partial nitritation, including a combination of high free ammonia and low dissolved oxygen under continuous aeration, as well as an intermittent aeration cycle with varying cycle lengths.

\section{Materials and Methods}

\subsection{Experimental Setup of Moving Bed Biofilm Reactor}

The schematic diagram of the experimental setup of the lab-scale MBBR reactor is depicted in Figure 3. The reactor had a working volume of $10.5 \mathrm{~L}$, of which $5 \mathrm{~L}$ was filled with the BWTS ${ }^{\circledR}$ bio-carriers (dimensions: $14.5 \times 18.5 \times 7.3 \mathrm{~mm}$ and protected surface: $650 \mathrm{~m}^{2} / \mathrm{m}^{3}$, from Biowater Technology AS), resulting in a total surface area of carrier and effective water volume of $3.25 \mathrm{~m}^{2}$ and $8 \mathrm{~L}$, respectively. Among $5 \mathrm{~L}$ of the carrier $3 \mathrm{~L}$ was obtained from a pilot nitrification-denitrification moving bed biofilm reactor 
(MBBR) at Knarrdalstrand Wastewater Treatment Plant (KRA) in Porsgrunn, Norway. The MBBR reactor was continuously fed with synthetic wastewater through a peristaltic pump (IsmatecTM ISM795C) from a $20 \mathrm{~L}$ influent vessel (Duran glass bottle). The continuous aeration was provided in the reactor by means of the aerator (Sera air 550R, Germany) and was connected with the aeration control box (Draeger air control) for the intermittent aeration cycle. The reactor was wrapped with PTFE-insulated heating tape (ISOHEAT, Germany) to maintain a temperature of $30 \pm 1{ }^{\circ} \mathrm{C}$ throughout the experimental period. The mechanical stirrer (i.e., Joanlab digital overhead stirrer) was inserted from the top and rotation speed was set to $140 \mathrm{rpm}$ (i.e., revolution per minute) for uniform movement of the biofilm inside the reactor. Moreover, the reactor was completely wrapped from outside with a black rubber plastic insulation sheet to protect the active biofilm from the sunlight.

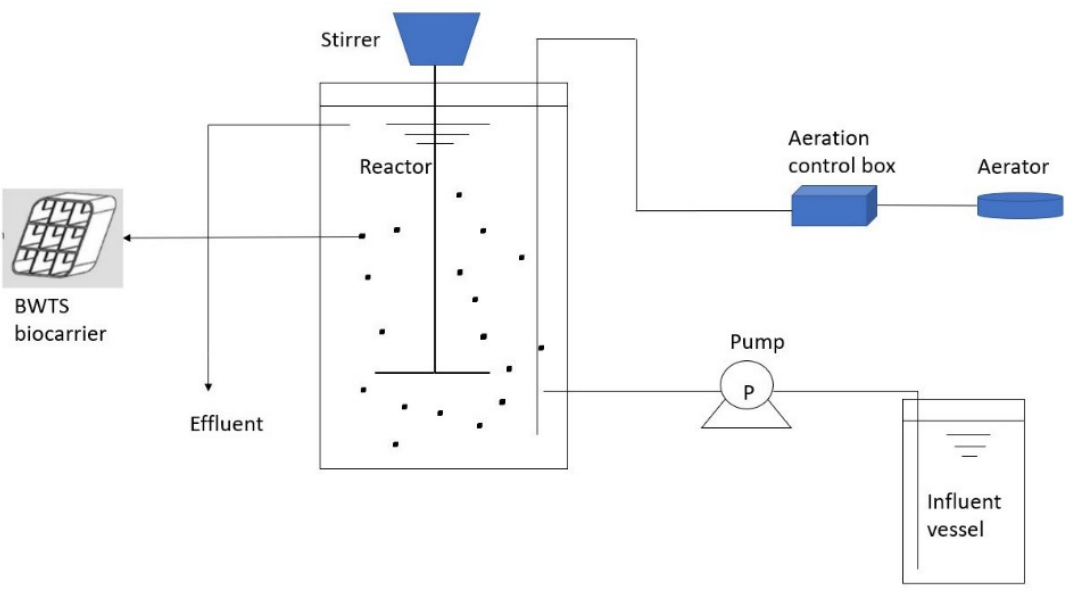

Figure 3. A schematic diagram of the experimental setup of MBBR reactor.

\subsection{Operating Conditions}

Two different surface ammonium loading rates (SALR), which were achieved by varying the influent flow rate, were applied in the reactor under continuous aeration as operating conditions up to the experimental period, day 59. Then, the strategy was changed to intermittent aeration, and four different sets of intermittent aeration cycles, from now onwards called IAC-1, IAC-2, IAC-3, IAC-4, were tested. The reactor operations details, such as hydraulic retention time (HRT), SALR, and flow rate for continuous aeration and cycle length with DO for intermittent aeration, for each test period, is shown in Table 1.

Table 1. Details of different operating conditions.

\begin{tabular}{cccccc}
\hline \multicolumn{1}{c}{ Continuous Aeration } \\
\hline S.N. & $\begin{array}{c}\text { Flow Rate } \\
\text { (L/d) }\end{array}$ & HRT (d) & SALR $\left(\mathbf{g N} / \mathbf{m}^{2} \cdot \mathbf{d}\right)$ & Duration \\
\hline 1 & 3.3 & 2.4 & $0.14 \pm 0.1$ & Day1-day 21 \\
\hline 2 & 6.5 & 1.2 & $0.27 \pm 0.005$ & Day 21-day 59 \\
\hline \multicolumn{1}{c}{ Test } & $\begin{array}{c}\text { Cycle } \\
\text { Length (min) }\end{array}$ & $\begin{array}{c}\text { Intermittent Aeration } \\
\text { Aerated/Non- } \\
\text { Aerated Time }\end{array}$ & $\begin{array}{c}\text { Aerated/Non } \\
\text { aerated DO } \\
(\mathbf{m i n} / \mathbf{m i n})\end{array}$ & $\begin{array}{c}\text { HRT } \\
\mathbf{( d )}\end{array}$ & Duration \\
\hline IAC-1 & 40 & $15 / 25$ & $1 / 0.1$ & 1.2 & Day 59-day 79 \\
\hline IAC-2 & 45 & $15 / 30$ & $0.6 / 0.05$ & 1.2 & Day 86-day 93 \\
\hline IAC-3 & 50 & $15 / 35$ & $0.5 / 0.05$ & 1.2 & Day 93-day 106 \\
\hline IAC-4 & 40 & $10 / 30$ & $0.5 / 0.025$ & 1.2 & Day 106-day 129 \\
\hline
\end{tabular}




\subsection{Synthetic Wastewater}

The simulated synthetic wastewater was prepared fresh every two-days by using tap water. According to the calculated stoichiometry mass balance, by adding the appropriate amount of ammonium chloride $\left(\mathrm{NH}_{4} \mathrm{Cl}\right)$ and sodium bicarbonate $\left(\mathrm{NaHCO}_{3}\right)$, the concentrations of ammonium-nitrogen $\left(\mathrm{NH}_{4}-\mathrm{N}\right)$ and alkalinity as $\mathrm{CaCO}_{3}$ were kept at $140 \mathrm{mg} / \mathrm{L}$ and 500-1100 mg/L, respectively. In addition, vitamins, and minerals solutions with a concentration of $1 \mathrm{ml} / \mathrm{L}$ of each were added in the synthetic wastewater as micronutrients. The composition of vitamins and minerals (Table 2) was the same as adopted by Dinamarca and Bakke [19]. During feed preparation, as well as while feeding the reactor, the whole mixture was always placed on the magnetic stirrer (Stuart UC151 magnetic stirrer) for the homogeneity of the solution.

Table 2. The composition of vitamins and minerals solutions in the synthetic wastewater.

\begin{tabular}{cccc}
\hline Vitamin Composition & $(\mathrm{g} / \mathrm{L})$ & Mineral Composition & $(\mathrm{g} / \mathrm{L})$ \\
\hline Thioctic acid & 0.05 & & \\
p-aminobenzoic acid & 0.05 & $\mathrm{CuSO}_{4} \cdot 5 \mathrm{H}_{2} \mathrm{O}$ & 0.055 \\
Pantothentic acid & 0.05 & $\mathrm{MnSO}_{4} \cdot \mathrm{H}_{2} \mathrm{O}$ & 0.04 \\
Vitamin B12 & 0.001 & $\mathrm{FeSO}_{4} \cdot 7 \mathrm{H}_{2} \mathrm{O}$ & 2.7 \\
Thiamine & 0.05 & $\mathrm{NiCl}_{2} \cdot 6 \mathrm{H}_{2} \mathrm{O}$ & 0.1 \\
Nicotinic acid & 0.05 & $\mathrm{ZnSO}_{4} \cdot 7 \mathrm{H}_{2} \mathrm{O}$ & 0.088 \\
Riboflavin & 0.05 & $\mathrm{CoCl}_{2} \cdot 6 \mathrm{H}_{2} \mathrm{O}$ & 0.05 \\
Pyridoxine hydrochloride & 0.1 & $\mathrm{H}_{3} \mathrm{BO}_{3}$ & 0.05 \\
Folic acid & 0.02 & & \\
Biotin & 0.02 & &
\end{tabular}

\subsection{Wastewater Constituients Analysis}

The wastewater samples from the inlet and outlet of the reactor were taken on a daily basis, except on a few occasions where samples were taken in a one-day gap. The samples (two of each from inlet and outlet in parallel) were analysed for the nitrogen compounds (i.e., ammonium $\left(\mathrm{NH}_{4}-\mathrm{N}\right)$, nitrite $\left(\mathrm{NO}_{2}-\mathrm{N}\right)$, nitrate $\left(\mathrm{NO}_{3}-\mathrm{N}\right)$, alkalinity analysis, and $\mathrm{pH}$ measurement, whereas onsite measurements, such as DO, and temperature, were measured every day during the experimental period. For all samples, the bio-chemical analysis was done using a cell test (test kit) method and the measurements were done by the Spectroquant ${ }^{\circledR}$ Pharo 300 UV /VIS photometer (Merck KGaA, Darmstadt, Germany). The cell test method is analogous to the US standard method of numbers 114,559, 100,609, 114,563 and 101,758 for the $\mathrm{NH}_{4}-\mathrm{N}, \mathrm{NO}_{2}-\mathrm{N}, \mathrm{NO}_{3}-\mathrm{N}$, and alkalinity as $\mathrm{CaCO}_{3}$ analysis, respectively [20]. The temperature and dissolved oxygen (DO) of the reactor were measured by WTW Oxi 3310 (Weilheim, Germany). In addition, The Beckman 390 pH meter was used to measure the $\mathrm{pH}$ of the samples.

The concentrations of nitrogen compounds in the synthetic wastewater obtained from laboratory analysis were quantified in terms of the surface ammonium loading rate (SALR), nitrate production rate (NPR), nitrite accumulation rate (NAR), ammonium removal efficiency (ARE), and was calculated by using Equations (3)-(6). Moreover, the hydraulic retention time (HRT) was calculated by using Equation (7).

$$
\begin{gathered}
\text { SALR }\left[\frac{\mathrm{gN}}{\mathrm{m}^{2} \mathrm{~d}}\right]=\frac{\mathrm{C}_{\mathrm{NH} 4-\mathrm{N}, \text { in }} \times \mathrm{Q}}{\mathrm{A}_{\text {carrier }} \times 1000} \\
\mathrm{NPR}[\%]=\frac{\left(\mathrm{C}_{\mathrm{NO} 3-\mathrm{N}, \text { out }}-\mathrm{C}_{\mathrm{NO} 3-\mathrm{N}, \text { in }}\right)}{\left(\mathrm{C}_{\mathrm{NH} 4-\mathrm{N}, \text { in }}-\mathrm{C}_{\mathrm{NH} 4-\mathrm{N}, \text { out }}\right)} \times 100 \\
\mathrm{NAR}[\%]=\frac{\left(\mathrm{C}_{\mathrm{NO} 2-\mathrm{N}, \text { out }}-\mathrm{C}_{\mathrm{NO} 2-\mathrm{N}, \text { in }}\right)}{\left(\mathrm{C}_{\mathrm{NH} 4-\mathrm{N}, \text { in }}-\mathrm{C}_{\mathrm{NH} 4-\mathrm{N}, \text { out }}\right)} \times 100 \\
\operatorname{ARE}[\%]=\frac{\left(\mathrm{C}_{\mathrm{NH} 4-\mathrm{N}, \text { in }}-\mathrm{C}_{\mathrm{NH} 4-\mathrm{N}, \text { out }}\right)}{\mathrm{C}_{\mathrm{NH} 4-\mathrm{N}, \text { in }}} \times 100
\end{gathered}
$$




$$
\mathrm{HRT}=\frac{\mathrm{V}}{\mathrm{Q}}
$$

where, $\mathrm{C}_{\mathrm{NH} 4-\mathrm{N}, \text { in }}=$ Inlet ammonium concentration $[\mathrm{mg} / \mathrm{L}]$ or total ammonium nitrogen (TAN)

$\mathrm{C}_{\mathrm{NH} 4-\mathrm{N}, \text { out }}=$ Outlet ammonium concentration $[\mathrm{mg} / \mathrm{L}]$

$A_{\text {carrier }}=$ Total surface area of carrier $\left[\mathrm{m}^{2}\right]=$ Protected surface area of carrier $\left[\mathrm{m}^{2} / \mathrm{m}^{3}\right]$ $\times$ total volume of carrier $\left[\mathrm{m}^{3}\right]$

$\mathrm{C}_{\mathrm{NO} 3-\mathrm{N}, \text { in }}=$ Inlet nitrate concentration $[\mathrm{mg} / \mathrm{L}]$

$\mathrm{C}_{\mathrm{NO} 3-\mathrm{N} \text {,out }}=$ Outlet nitrate concentration $[\mathrm{mg} / \mathrm{L}]$

$\mathrm{C}_{\mathrm{NO} 2-\mathrm{N}, \mathrm{in}}=$ Inlet nitrite concentration $[\mathrm{mg} / \mathrm{L}]$

$\mathrm{C}_{\mathrm{NO} 2-\mathrm{N} \text {,out }}=$ Outlet nitrite concentration $[\mathrm{mg} / \mathrm{L}]$

$\mathrm{Q}=$ Water flow rate $[\mathrm{L} / \mathrm{d}]$

$\mathrm{V}=$ Effective water volume inside the reactor [L]

The operating conditions such as dissolved oxygen (DO) concentration expressed as the ratio of DO and total ammonium nitrogen (TAN), surface ammonia loading rate (SALR), and aeration strategy were applied based on two requirements of partial nitritation: (i) around $50 \%$ of ammonia removal efficiency (ARE), and (ii) almost none (i.e., $0 \%$ ) nitrate production rate (NPR) or $100 \%$ nitrite accumulation rate (NAR). From now onwards, these requirements are mentioned as first and second requirement, respectively.

\subsection{Data Analysis}

The data generated from the biochemical analysis and onsite measurement were processed in Microsoft Excel for data visualization, mass balance analysis and standard plotting. The mean of each biochemical and physical parameter measurements over time were used for the statistical comparisons.

\section{Results and Discussion}

\subsection{Synthetic Medium Concentration and Operating Conditions}

The influent ammonium concentration $(\approx 140 \mathrm{mg} / \mathrm{L})$ was chosen based on the two major factors, which are essential for the anammox start-up: (i) the FA concentration should be between 1 and $10 \mathrm{mg} / \mathrm{L}$ for the NOB suppression and to promote AOB and anammox simultaneously [21], and (ii) the accumulated nitrite concentration should be between $40-60 \mathrm{mg} / \mathrm{L}$ [22]. Reactor temperature and $\mathrm{pH}$ were maintained around $30^{\circ} \mathrm{C}$ and 7.8 , respectively, during the experimental period, which had created a conductive environment for anammox growth [23]. The temperature and $\mathrm{pH}$ resulted in FA less than $10 \mathrm{mg} / \mathrm{L}$, and the partial nitritation yielding below $60 \mathrm{mg} / \mathrm{L}$ nitrite concentration. In addition, the alkalinity provided was sufficient to compensate for the hydrogen ions produced by partial nitritation. Stoichiometrically, 2.0 mole of alkalinity (as $\mathrm{HCO}_{3}{ }^{-}$) is required to maintain a stable $\mathrm{pH}$ for 1.0 moles of $\mathrm{NH}_{4}-\mathrm{N}$ oxidation (Equation (1)), which is equivalent to $7.14 \mathrm{~g}$ alkalinity as $\mathrm{CaCO}_{3}$ required for $1 \mathrm{~g}$ of $\mathrm{NH}_{4}-\mathrm{N}$ oxidation.

\subsection{Nitrogen Compounds Transformations in Different SALR under Continuous Aeration}

The transformation of influent ammonium to nitrite and nitrate, along with their accumulation rate under the continuous aeration experimental period, is shown in Figure 4. During this period the reactor was subjected to a low influent flow rate of $3.3 \mathrm{~L} / \mathrm{d}$ from the start to day 21, which resulted in HRT and SALR of $2.42 \mathrm{~d}$ and $0.14 \pm 0.1 \mathrm{gN} / \mathrm{m}^{2} \cdot \mathrm{d}$, respectively. Up to day 10, when the reactor's DO/TAN ratio was greater than 0.025 , there was close to $90 \%$ ARE, resulting in a $10 \mathrm{mg} / \mathrm{L}$ ammonium concentration in the outlet. NPR was initially lower during this period, but it steadily climbed over time. NAR, on the other hand, was on the rise, reaching a peak value of nearly $90 \%$ on day 7 , resulting in an $\mathrm{NO}_{2}-\mathrm{N}$ outlet concentration of $115 \mathrm{mg} / \mathrm{L}$, before it began to fall (Figure $4 \mathrm{~b}$ ). The observed higher accumulation of nitrite than nitrate in this period was due to the faster recovery time of AOB [13]. The biomass on the old carriers was under critical starvation of substrate while being transferred from KRA to the lab reactor; when it has got substrate from synthetic 
wastewater, the AOB populations were more active than NOB. Moreover, the nitrogen mass balance analysis showed that, on day 3 , there was a significant quantity of nitrogen gas production, which was due to the activity of heterotrophic bacteria present in the old bio carrier with a COD source from endogenous decay [24]. However, later in the experimental period, the activity of heterotrophic bacterial biomasses diminished due to the lack of COD source in the synthetic wastewater. Here, the nitrogen mass balance only considered the inlet and outlet's $\mathrm{NH}_{4}-\mathrm{N}, \mathrm{NO}_{2}-\mathrm{N}$, and $\mathrm{NO}_{3}-\mathrm{N}$, but in fact, additional compounds such as nitric oxide (NO) and nitrous oxide $\left(\mathrm{N}_{2} \mathrm{O}\right)$ were also assessed. Therefore, there was negative nitrogen gas production observed from the mass balance analysis on some days. Thus, in this experimental period, the DO/TAN value higher than 0.025 did not meet the first requirement of partial nitritation. Hence, the aeration rate was further decreased in the subsequent test.

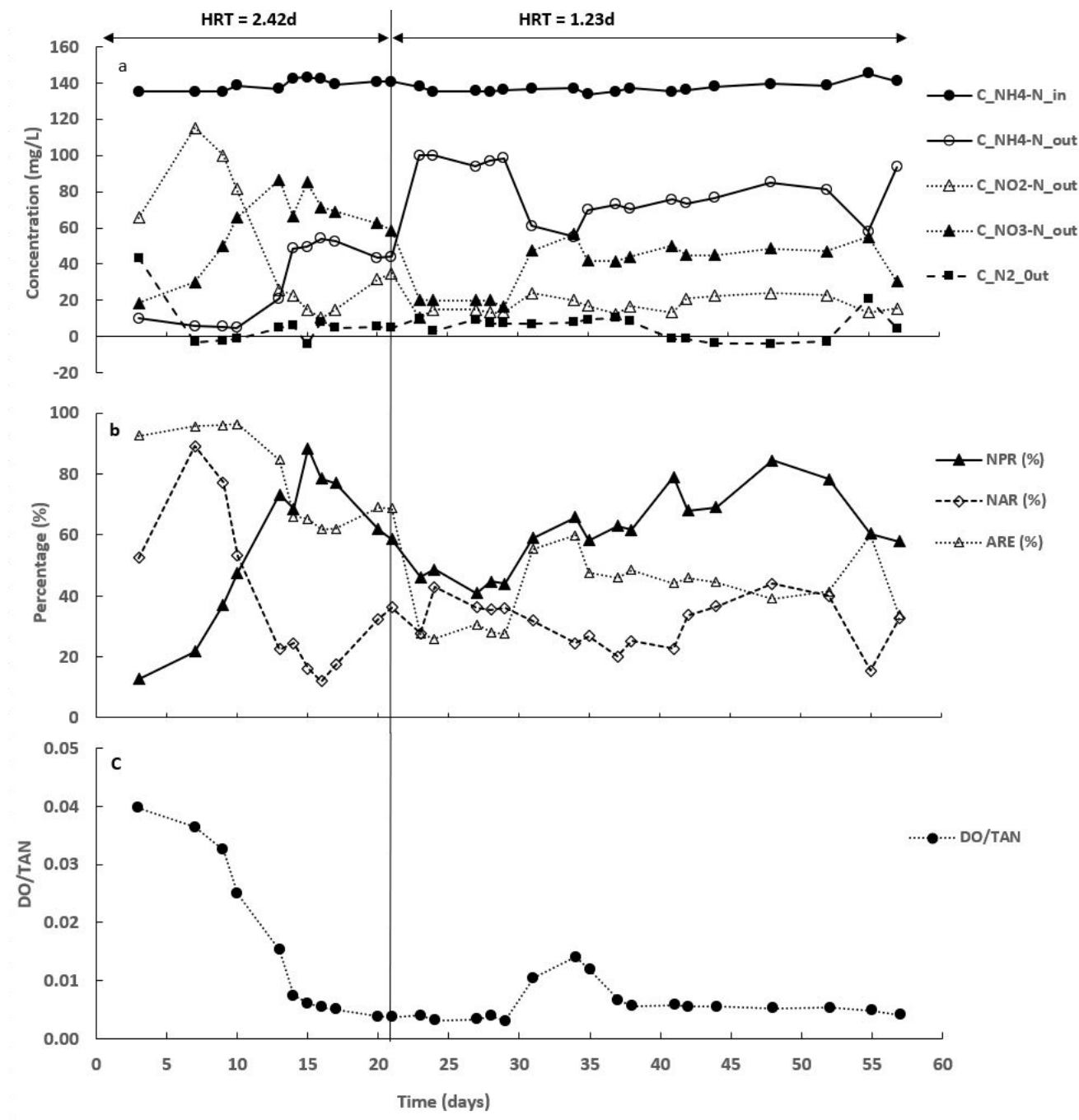

Figure 4. Nitrogen compounds transformation under continuous aeration: (a) inlet and outlet nitrogen compounds variations; (b) Production and removal percentage of nitrogen compounds; (c) DO/TAN ratio as an operating parameter.

From day 10 to day 15, the DO/TAN ratio was gradually reduced to 0.005 and applied steady until day 21. As the DO/TAN declined, ARE decreased substantially as well, eventually stabilizing at $65 \%$, which was a promising value in terms of the first requirement of partial nitritation (i.e., around 50\% ARE) when the DO/TAN became stable. Despite the decrement in the DO/TAN ratio, the NPR was continuously increased and reached a peak value of $88 \%$ on day 15 , resulting in $85 \mathrm{mg} / \mathrm{L} \mathrm{NO}_{3}-\mathrm{N}$ in the outlet (Figure $4 \mathrm{~b}$ ). On the other 
hand, the NAR was significantly decreased and became close to $15 \%$. However, afterwards, the NPR and NAR trends were altered, i.e., a decrease in NPR and an increase in NAR, but did not reach the second requirement of partial nitritation (i.e., almost $0 \% \mathrm{NPR}$ or $100 \%$ NAR). Therefore, on a subsequent test, the SALR was increased to $0.27 \pm 0.005 \mathrm{gN} / \mathrm{m}^{2} \cdot \mathrm{d}$ from day 21 by increasing the influent flow rate to $6.5 \mathrm{~L} / \mathrm{d}$, which had decreased the HRT by half to $1.2 \mathrm{~d}$.

When the SALR was increased, while the DO/TAN ratio was kept similar, ARE dropped significantly from $65 \%$ to $27 \%$. This shows that, for low HRT to attain the same ARE as in high HRT, a large amount of DO/TAN is required, which signifies that the DO/TAN and HRT had an inverse relation to achieve same ARE. Hence, the DO/TAN was increased to bring the reactor $\mathrm{NH}_{4}-\mathrm{N}$ accumulation close to the first requirement of partial nitritation. As the DO/TAN ratio was increased starting from 0.005 on day 30 , ARE was also increased and became around $48 \%$ when DO/TAN was around 0.015 on day 34 (Figure 4c). At these operating conditions, the reactor was behaving promising in terms of the first requirement of partial nitritation, but the NPR and NAR was $65 \%$ and $24 \%$, respectively. This resulted in $56 \mathrm{mg} / \mathrm{L}$ of $\mathrm{NO}_{3}-\mathrm{N}$ and $20 \mathrm{mg} / \mathrm{L} \mathrm{NO}_{2}-\mathrm{N}$ accumulation in the reactor, which was far from the second requirement of partial nitritation. Therefore, the DO/TAN was decreased and was maintained stable with a value around 0.005 from day 38 .

ARE followed the same trends as DO/TAN and became closely stable with an average value of $44.7 \%$, which was close to the first requirement. However, the average value of NPR and NAR was far from the second requirement, which was around $72 \%$ and $32 \%$, respectively. As a result, the average $\mathrm{NO}_{3}-\mathrm{N}$ production and $\mathrm{NO}_{2}-\mathrm{N}$ accumulation were $45.6 \mathrm{mg} / \mathrm{L}$ and $18.7 \mathrm{mg} / \mathrm{L}$, which was an insufficient substrate for the anammox process while it promoted NOB activity.

Shortly, continuous aeration and up to SALR of $0.27 \pm 0.005 \mathrm{gN} / \mathrm{m}^{2} \cdot \mathrm{d}$ did not create $\mathrm{PN}$ conditions, despite that the reactor was operated with different $\mathrm{DO} / \mathrm{TAN}$ ratio ranging from $0.005-0.04$. Even with a far lower value than 0.25 for NOB suppression, as reported by Bartrolí et al. [25], the NPR was higher than NAR. The same result was observed by Schopf et al. [10] in the MBBR reactor with $0.11 \mathrm{DO} / \mathrm{TAN}$ and up to SALR of $6.5 \mathrm{gN} / \mathrm{m}^{2} \cdot \mathrm{d}$. The failure in achieving partial nitritation was due to small biofilm thickness, which had resulted in the sufficient diffusion of the oxygen in the inner part of the biofilm where NOB lies, even though the DO/TAN ratio was extremely low. Similarly, Choi et al. [26] did not observe partial nitritation due to the growth of Nitrospira spp. when the SALR was below $2.16 \mathrm{~kg} \mathrm{~N} / \mathrm{m}^{3} \cdot \mathrm{d}$. The Nitrospira spp. are the k-strategists type NOB bacteria, whose growth is favorable in the wastewater having low ammonium concentration and below $2 \mathrm{mg} / \mathrm{L}$ DO [26,27]. Therefore, we conclude that the failure to achieve partial nitritation could be due to either low biofilm thickness or due to the dominant Nitrospira spp., or a combination of both. Furthermore, During the whole time of the continuous aeration, the average free ammonia concentration was $6.59 \pm 3.5 \mathrm{mg} / \mathrm{L}$, which was higher than the inhibition range of NOB; however, this high concentration of FA also couldn't suppress NOB because they became adapted and resilient to FA inhibition as time went on [28].

In our observation, the high SALR of $0.27 \pm 0.005 \mathrm{gN} / \mathrm{m}^{2} \cdot \mathrm{d}$ was a bit closer to partial nitritation as NPR was lower, and NAR was higher than low SALR of $0.14 \pm 0.1 \mathrm{gN} / \mathrm{m}^{2} \cdot \mathrm{d}$ under $0.0053 \mathrm{DO} / \mathrm{TAN}$ ratio (Figure 5). Hence, the highest degree in SALR could give complete partial nitritation because it mitigated both possible reasons for NOB activity: (i) lower thickness of biofilm and (ii) growth of Nitrospira spp. However, the SALR was not increased over $0.27 \pm 0.005 \mathrm{gN} / \mathrm{m}^{2} \cdot \mathrm{d}$, because increasing SALR requires increasing either the influent flow rate or the influent ammonium concentrations. Both factors contribute to a poor anammox start-up environment since a flow rate greater than $6.5 \mathrm{~L} / \mathrm{d}$ leads to significantly lower HRT than what was found by Klaus et al. [29], who reported $33 \mathrm{~h} \mathrm{HRT}$ for a successful anammox start-up, and increasing ammonium concentration increases free ammonia levels to greater than $10 \mathrm{mg} / \mathrm{L}$. Moreover, low HRT facilitates washout of microorganisms, especially the anammox microorganisms that need time for extracellular 
polymeric substances (EPS) production for stable biofilm formation and aggregation [30]. Hence, to avoid both strategies in the subsequent test, the aeration strategy was changed from continuous to intermittent.

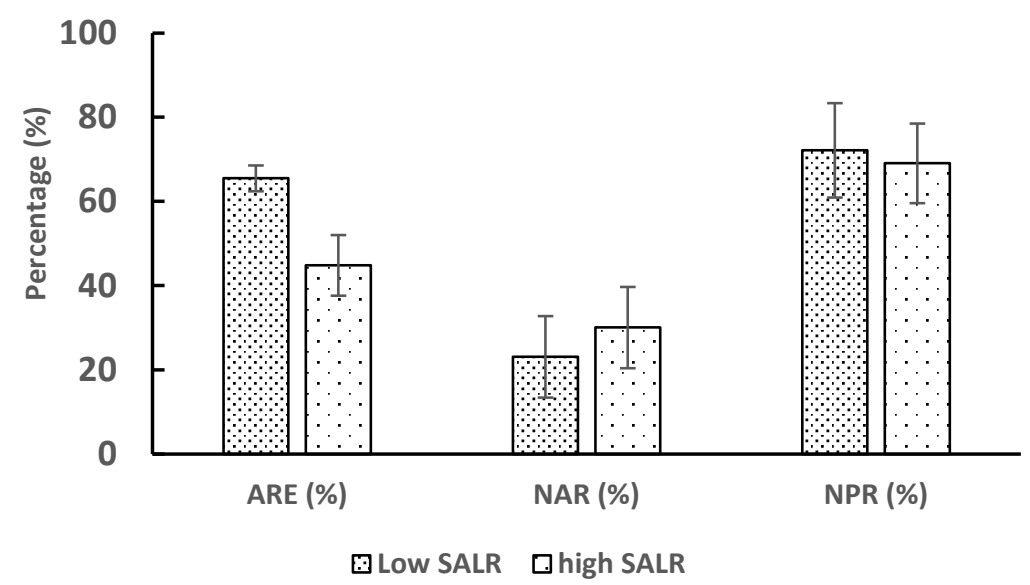

Figure 5. Effect of SALR on nitrogen compounds transformations under same DO/TAN ratio. Error bars are the standard deviations calculated from six samples.

\subsection{Effect of Intermittent Aeration Cycle on Nitrogen Compounds Transformation}

When the SALR was $0.27 \mathrm{gN} / \mathrm{m}^{2} \cdot \mathrm{d}$ under continuous aeration, the reactor had roughly $50 \%$ ARE at $0.0056 \mathrm{DO} / \mathrm{TAN}$, equivalent to $0.78 \mathrm{mg} / \mathrm{L} \mathrm{DO}$. Hence, it was decided to use an intermittent aeration cycle with $0.8-1 \mathrm{mg} / \mathrm{L} \mathrm{DO}$ in the aerobic phase and roughly $0.1 \mathrm{mg} / \mathrm{L}$ $\mathrm{DO}$ in the anaerobic phase. The reactor was tested with a variety of intermittent aeration cycle (IAC) lengths and aeration rates, and the desired profile was eventually achieved with the cycle length of $15 \mathrm{~min}$ ON and $25 \mathrm{~min}$ OFF (IAC-1) (Figure 6a) and applied in the reactor from day 59. Figure 7 shows the transformation of influent ammonium into nitrite and nitrate under different set of intermittent aeration cycle. ARE began to fall when the intermittent aeration cycle was first introduced, reaching $26 \%$ on day 63 , due to the biofilm's inability to quickly acclimate to the new environment [8]. ARE was steadily increased by consuming DO from the bulk liquid, reaching $44 \%$ on day 79 , the same as before the intermittent aeration cycle was introduced. As a result, the DO concentration in the intermittent aeration cycle fell and became $0.5 \mathrm{mg} / \mathrm{L}$ and $0.075 \mathrm{mg} / \mathrm{L}$ in aerated and non-aerated phases (IAC- $\left.1^{\prime}\right)$, respectively. The $\mathrm{NO}_{3}-\mathrm{N}$ in the outlet was stable at $26 \mathrm{mg} / \mathrm{L}$ on that period, signifying that the consumed ammonium over the time was accumulated as $\mathrm{NO}_{2}-\mathrm{N}$, reaching $46 \mathrm{mg} / \mathrm{L}$ on day 79 , which indicates the partial nitritation. As a result, NAR crossed over the NPR value on day 69 and reached $78 \%$ on day 79 . After that day, when IAC-1 was stabilized, IAC-1', ARE and NAR were also stable; however, the NPR kept on decreasing. As a result, the $\mathrm{NO}_{3}-\mathrm{N}$ in the outlet began to fall and reached $20 \mathrm{mg} / \mathrm{L}$ on day 86 , indicating that the NOB was inhibited even more than before. This operating condition resulted in a promising ARE; however, the NPR and NAR value was not close to the second requirement (i.e., almost $0 \%$ NPR or $100 \%$ NAR). Hence, in the subsequent test, the cycle length of the intermittent aeration cycle was changed.

The non-aerated length in the IAC-1 was extended by 5 min to make an intermittent aeration cycle length of $15 \mathrm{~min} O N$ and $30 \mathrm{~min}$ OFF with DO concentration around $0.1 \mathrm{mg} / \mathrm{L}$ higher than IAC-1' in the aerobic phase, which was IAC-2 (Figure 6b) and applied from day 85. No significant change in nitrogen compound transformation was observed with this intermittent aeration cycle. This was due to the increased anoxic time that was balanced by the higher DO in the aerobic phase. Hence, another intermittent aeration cycle IAC-3 was applied from day 93, which had the non-aerated cycle length 10 min higher than IAC-1 and with the same aerated phase DO as in IAC-1' (Figure 6c). As soon as this intermittent aeration cycle was applied, ARE started to fall sharply to reach $30 \%$ on day 106 , lower than the first requirement of partial nitritation. The decrement in ARE had a greater effect on the 
AOB than $\mathrm{NOB}$ as $\mathrm{NO}_{2}-\mathrm{N}$ in the outlet was sharply decreased compared to $\mathrm{NO}_{3}-\mathrm{N}$, even though both the NPR and NAR profile was steady. This was attributed to the intermittent aeration cycle's longer anoxic period than IAC-1, which did not encourage AOB activity.
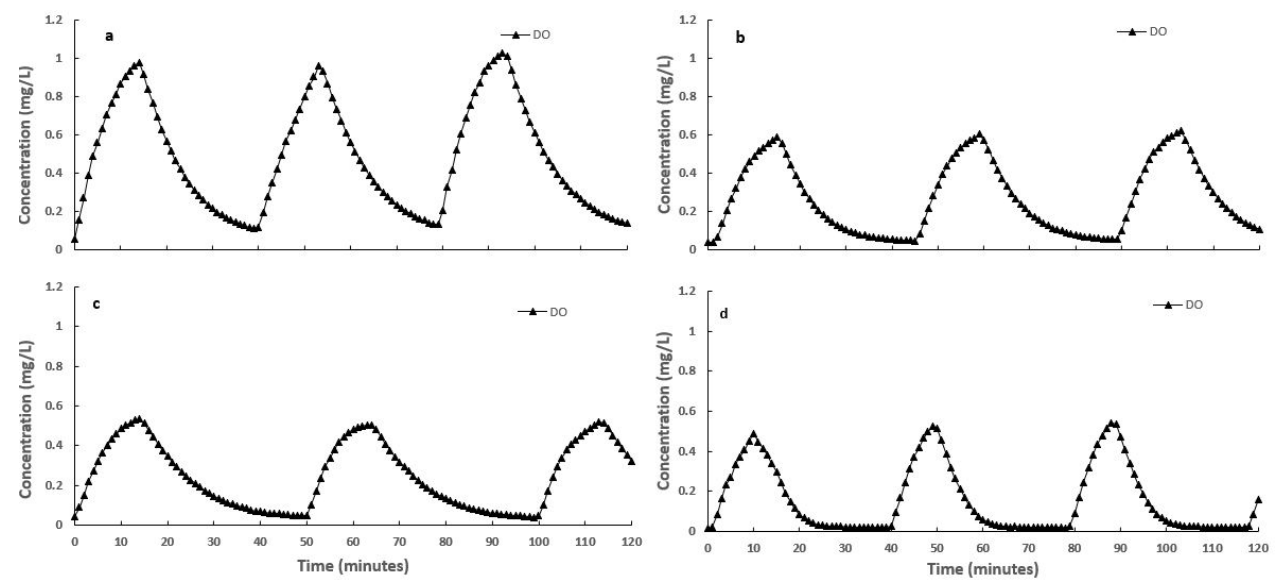

Figure 6. Different intermittent aeration cycle with DO profile: (a) Intermittent aeration cycle with cycle length $15 \mathrm{~min}$ ON/25 min OFF (IAC-1); (b) Intermittent aeration cycle with cycle length $15 \mathrm{~min}$ ON/30 min OFF (IAC-2); (c) Intermittent aeration cycle with cycle length $15 \mathrm{~min}$ ON/35 min OFF (IAC-3); (d) Intermittent aeration cycle with cycle length $10 \mathrm{~min}$ ON/30 $\mathrm{min}$ OFF (IAC-4).

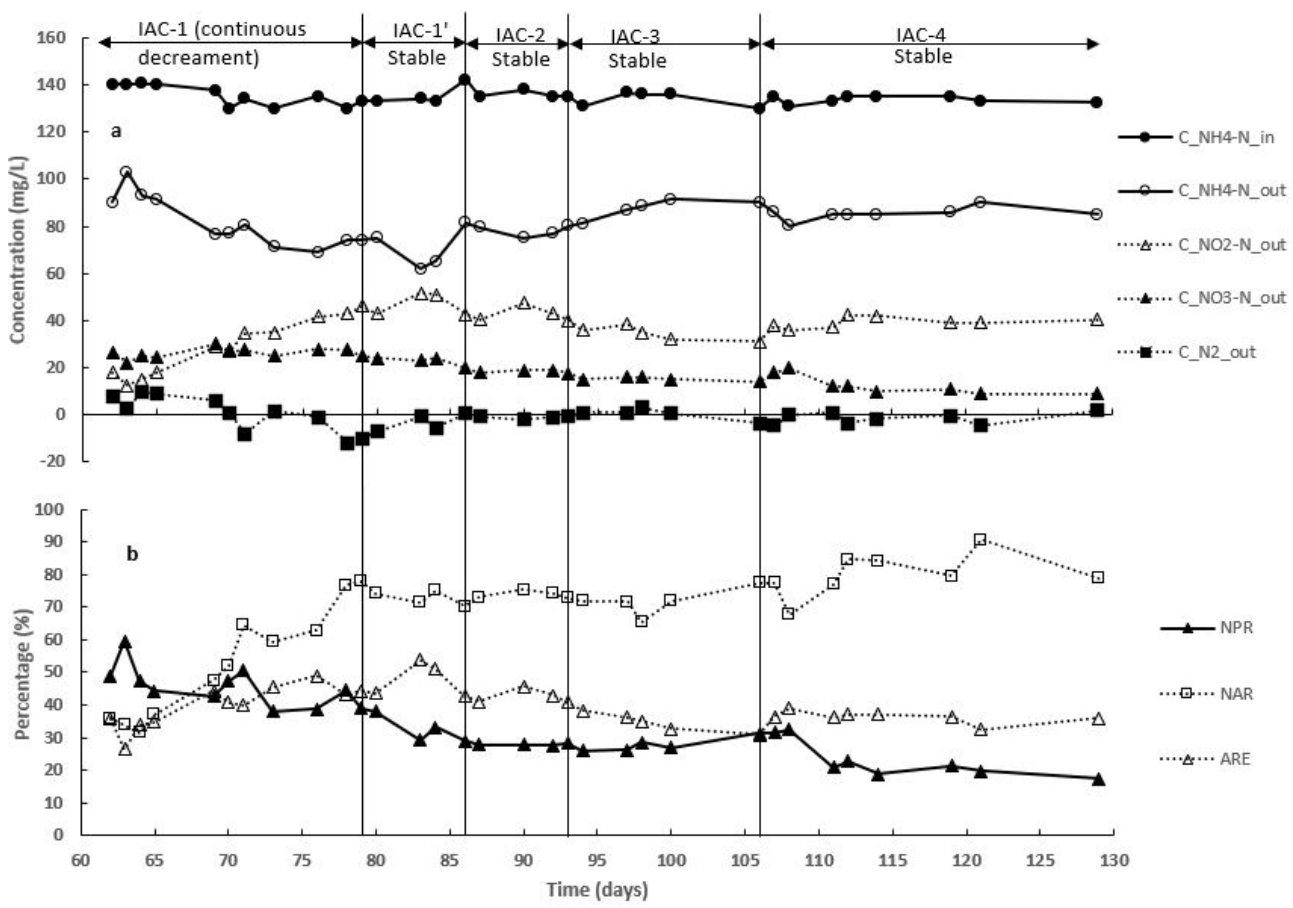

Figure 7. Nitrogen compounds transformation under intermittent aeration: (a) Nitrogen compounds variations; (b) Nitrogen compounds accumulation and removal efficiency.

Hence, in a subsequent test, another intermittent aeration cycle was applied. The DO profile of the intermittent aeration cycle IAC-4 is depicted in the Figure 6d. The cycle length of this intermittent aeration cycle was chosen based on the cycle length of IAC-2. The time extension in the anoxic phase in IAC-2 to make IAC-3 resulted in the ARE lower than the requirement for partial nitritation, and $15 \mathrm{~min}$ ON time did not suppress NOB as required by the second requirement. Hence, the cycle length of $10 \mathrm{~min}$ ON/30 min OFF was obtained by maintaining the same anoxic time and aerobic time was shorted by $5 \mathrm{~min}$. When this cycle was applied, ARE starts to rise slowly, resulting in an average ARE 
of 37\%. The NPR was gradually decreasing, whereas NAR shows the increasing trends, reaching $17 \%$ and $78 \%$, respectively, on day 129 . The outlet $\mathrm{NO}_{3}-\mathrm{N}$ and $\mathrm{NO}_{2}-\mathrm{N}$, on the other hand, had a concentration of $9 \mathrm{mg} / \mathrm{L}$ and $40.5 \mathrm{mg} / \mathrm{L}$, respectively. In terms of partial nitritation, the above-mentioned conversion rate and concentrations look promising. On top of that, more suppression of $\mathrm{NOB}$, in this case, was due to the shorter aerated length of the intermittent aeration cycle (Table 1), which gave less chance for activity of NOB after starvation.

However, a study carried out by Zhou et al. [8] in sequential batch reactor (SBR) with synthetic wastewater has successfully suppressed NOB using an intermittent aeration cycle having lengths of $20 \mathrm{~min} \mathrm{ON}$ and $20 \mathrm{~min}$ OFF with $0.5 \mathrm{mg} / \mathrm{L} \mathrm{DO}$ in the aerated phase. Moreover, Kanders et al. [31] achieved partial nitritation by suppressing NOB bacteria with a cycle length of $45 \mathrm{~min}$ ON and 15 min OFF in MBBR (but DO was not reported), which was fed with reject water. Therefore, no specific optimum aerobic/anoxic length exists to suppress NOB and depends upon several factors, such as reactor configuration, type of wastewater and ammonium concentration in influent, and the proportion of the $\mathrm{AOB} / \mathrm{NOB}$ biofilm on the biocarriers.

\section{Conclusions}

In the anammox start-up environment within this study condition, the combination of low DO obtained from continuous aeration and high free ammonia could not give partial nitritation up to SALR of $0.27 \pm 0.005 \mathrm{gN} / \mathrm{m}^{2} \cdot \mathrm{d}$, as NPR was always higher than NAR. This result can be attributed to either growth of Nirospira spp., or low biofilm growth and thickness, or a combination of both. Increasing SALR to a high level, on the other hand, may result in partial nitritation but cannot be prolonged to one stage PNA due to the inadequate environment for anammox start-up. As a result, the aeration technique was altered to an intermittent aeration, and four different intermittent aeration cycles (IAC-1, IAC-2, IAC-3, IAC-4) were investigated. The intermittent aeration cycle having relatively shorter aeration length (i.e., $10 \mathrm{~min}$ ) in the aerobic phase and $30 \mathrm{~min}$ in the non-aerated phase (i.e., the test condition IAC-4) has resulted in successful partial nitritation because of less time available for NOB activation after starvation. However, the optimum length of aerobic/anoxic in intermittent aeration cycle can be different to different conditions. Therefore, a novel set of aerobic/anoxic lengths is required and can be achieved by the real time observation of the transformation of nitrogen compounds.

Author Contributions: Writing—original draft, S.P.; Writing—review and editing, S.P., E.J. and S.W.; Methodology, S.P., E.J. and S.W.; Data curation, S.P.; Conceptualization, S.P.; Funding acquisition, S.W. and E.J.; Supervision E.J. and S.W. All authors have read and agreed to the published version of the manuscript.

Funding: The research project "Efficient upgrading of municipal wastewater treatment plants (Project No: 269014)" was funded by the Research Council of Norway's "Oslofjordfondet". The APC was funded by the University of South-Eastern Norway.

Data Availability Statement: The related biochemical data from the laboratory analysis and their calculations can be found in the Dropbox link: https:/ / www.drobox.com/scl/fi/3bve2hj1ek4uz0ctz8 zq1/Data-and-calcultions.xlsx?dl=0\&rlkey=cmb9wk8hxjqszw8w7fjjayiy5 (accessed on 25 November 2021).

Conflicts of Interest: The authors declare no conflict of interest.

\section{References}

1. Ahn, Y.-H. Sustainable nitrogen elimination biotechnologies: A review. Process Biochem. 2006, 41, 1709-1721. [CrossRef]

2. Van Hulle, S.W.; Vandeweyer, H.J.; Meesschaert, B.D.; Vanrolleghem, P.A.; Dejans, P.; Dumoulin, A. Engineering aspect and practical application of autotrophic nitrogen removal from nitrogen rich stream. Chem. Eng. J. 2010, 162, 1-20. [CrossRef]

3. Qiu, S.; Li, Z.; Hu, Y.; Shi, L.; Liu, R.; Shi, L.; Chen, L.; Zhan, X. What's the best way to achieve successful mainstream partial nitritation-anammox application? Crit. Rev. Environ. Sci. Technol. 2020, 51, 1-33. [CrossRef] 
4. Cao, Y.; van Loosdrecht, M.C.M.; Daigger, G.T. Mainstream partial nitritation-anammox in municipal wastewater treatment: Status, bottlenecks, and further studies. Appl. Microbiol. Biotechnol. 2017, 101, 1365-1383. [CrossRef]

5. Jetten, M.S.M.; Horn, S.J.; van Loosdrecht, M.C.M. Towards a more sustainable municipal wastewater treatment system. Sustain. Sanit. 1997, 35, 171-180. [CrossRef]

6. Qian, W.; Peng, Y.; Li, X.; Zhang, Q.; Ma, B. The inhibitory effects of free ammonia on ammonia oxidizing bacteria and nitrite oxidizing bacteria under anaerobic condition. Bioresour. Technol. 2017, 243, 1247-1250. [CrossRef]

7. Wiesmann, U. Biological nitrogen removal from wastewater. Adv. Biochem. Eng. Biotechnol. 1994, 51, 113-154.

8. Zhou, Z.; Qi, M.; Wang, H. Achieving Partial Nitrification via Intermittent Aeration in SBR and Short-Term Effects of Different C/N Ratios on Reactor Performance and Microbial Community Structure. Water 2020, 12, 3485. [CrossRef]

9. $\mathrm{Xu}, \mathrm{G}$. Partial nitrification adjusted by hydroxylamine in aerobic granules under high DO and ambient temperature and subsequent Anammox for low C/N wastewater treatment. Chem. Eng. J. 2012, 8, 338-345. [CrossRef]

10. Schopf, A.; Delatolla, R.; Kirkwood, K.M. Partial nitritation at elevated loading rates: Design curves and biofilm characteristics. Bioprocess Biosyst. Eng. 2019, 42, 1809-1818. [CrossRef]

11. Anthonisen, A.C.; Loehr, R.C.; Prakasam, T.B.; Srinath, E.G. Inhibition of Nitrification by Ammonia and Nitrous Acid. J. Water Pollut. Control Fed. 1976, 48, 835-852.

12. Ma, B.; Wang, S.; Cao, S.; Miao, Y.; Jia, F.; Du, R.; Peng, Y. Biological nitrogen removal from sewage via anammox: Recent advances. Bioresour. Technol. 2016, 200, 981-990. [CrossRef] [PubMed]

13. Li, J.; Elliott, D.; Nielsen, M.; Healy, M.G.; Zhan, X. Long-term partial nitrification in an intermittently aerated sequencing batch reactor (SBR) treating ammonium-rich wastewater under controlled oxygen-limited conditions. Biochem. Eng. J. 2011, 55, 215-222. [CrossRef]

14. Kostera, J.; Youngblut, M.D.; Slosarczyk, J.M.; Pacheco, A.A. Kinetic and product distribution analysis of NO* reductase activity in Nitrosomonas europaea hydroxylamine oxidoreductase. J. Biol. Inorg. Chem. 2008, 13, 1073-1083. [CrossRef]

15. Kampschreur, M.J.; Tan, N.C.G.; Kleerebezem, R.; Picioreanu, C.; Jetten, M.S.M.; Loosdrecht, M.C.M. van Effect of Dynamic Process Conditions on Nitrogen Oxides Emission from a Nitrifying Culture. Environ. Sci. Technol. 2008, 42, 429-435. [CrossRef]

16. Bakke, R. High Tech Process in Combination with Natural Systems. Msc Lecture Presentation; University of South-Eastern Norway: Notodden, Norway, 2018.

17. Eilersen, A.M.; Henze, M.; Kløft, L. Effect of volatile fatty acids and trimethylamine on nitrification in activated sludge. Water Res. 1994, 28, 1329-1336. [CrossRef]

18. Peng, Y.; Song, X.; Peng, C.; Li, J.; Chen, Y. Biological nitrogen removal in SBR bypassing nitrate generation accomplished by chlorination and aeration time control. Water Sci. Technol. J. Int. Assoc. Water Pollut. Res. 2004, 49, 295-300. [CrossRef]

19. Dinamarca, C.; Bakke, R. Apparent hydrogen consumption in acid reactors: Observations and implications. Water Sci. Technol. J. Int. Assoc. Water Pollut. Res. 2009, 59, 1441-1447. [CrossRef] [PubMed]

20. American Public Health Association; Eaton, A.D.; American Water Works Association; Water Environment Federation. Standard Methods for the Examination of Water and Wastewater; APHA-AWWA-WEF: Washington, DC, USA, 2005; ISBN 978-0-87553-047-5.

21. Dimitrova, I.; Dabrowska, A.; Ekström, S. Start-up of a full-scale partial nitritation-anammox MBBR without inoculum at Klagshamn WWTP. Water Sci. Technol. 2020, 81, 2033-2042. [CrossRef]

22. Kanders, L.; Ling, D.; Nehrenheim, E. Rapid start-up of one-stage deammonification MBBR without addition of external inoculum. Water Sci. Technol. 2016, 74, 2541-2550. [CrossRef] [PubMed]

23. Yang, Y.; Zuo, J.; Shen, P.; Gu, X. Influence of temperature, pH value and organic substance on activity of ANAMMOX sludge. Huan Jing Ke Xue Huanjing Kexue 2006, 27, 691-695.

24. Yumpu.com. Nitrification \& Denitrification-The Water Planet Company. Available online: https://www.yumpu.com/en/ document/view/11509528/nitrification-denitrification-the-water-planet-company (accessed on 15 September 2021).

25. Bartrolí, A.; Pérez, J.; Carrera, J. Applying Ratio Control in a Continuous Granular Reactor to Achieve Full Nitritation under Stable Operating Conditions. Environ. Sci. Technol. 2010, 44, 8930-8935. [CrossRef]

26. Choi, M.; Cho, K.; Jeong, D.; Chung, Y.-C.; Park, J.; Lee, S.; Bae, H. Effects of the ammonium loading rate on nitrite-oxidizing activity during nitrification at a high dose of inorganic carbon. J. Environ. Sci. Health Part A 2018, 53, 708-717. [CrossRef] [PubMed]

27. Wu, J.; He, C.; van Loosdrecht, M.C.M.; Pérez, J. Selection of ammonium oxidizing bacteria (AOB) over nitrite oxidizing bacteria (NOB) based on conversion rates. Chem. Eng. J. 2016, 304, 953-961. [CrossRef]

28. Duan, H.; Ye, L.; Lu, X.; Yuan, Z. Overcoming Nitrite Oxidizing Bacteria Adaptation through Alternating Sludge Treatment with Free Nitrous Acid and Free Ammonia. Environ. Sci. Technol. 2019, 53, 1937-1946. [CrossRef]

29. Klaus, S.; Baumler, R.; Rutherford, B.; Thesing, G.; Zhao, H.; Bott, C. Startup of a Partial Nitritation-Anammox MBBR and the Implementation of $\mathrm{pH}$-Based Aeration Control. Water Environ. Res. 2017, 89, 500-508. [CrossRef]

30. Jia, F.; Yang, Q.; Liu, X.; Li, X.; Li, B.; Zhang, L.; Peng, Y. Stratification of Extracellular Polymeric Substances (EPS) for Aggregated Anammox Microorganisms. Environ. Sci. Technol. 2017, 51, 3260-3268. [CrossRef]

31. Kanders, L.; Areskoug, T.; Schneider, Y.; Ling, D.; Punzi, M.; Beier, M. Impact of seeding on the start-up of one-stage deammonification MBBRs. Environ. Technol. 2014, 35, 2767-2773. [CrossRef] 